\title{
Velocity of sound in membranous bodies
}

\section{F. Melde}

To cite this article: F. Melde (1892) Velocity of sound in membranous bodies, Philosophical Magazine Series 5, 33:201, 236-236, DOI: 10.1080/14786449208621461

To link to this article: http://dx.doi.org/10.1080/14786449208621461

$$
\text { 曲 Published online: } 08 \text { May } 2009 .
$$

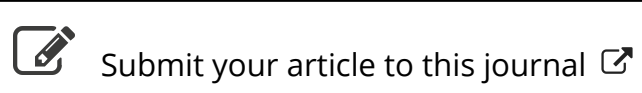

\footnotetext{
Џll Article views: 2
}

Q View related articles ¿ 


\section{VELOCITY OF SOUND IN MHMBRANOUS BODIES.}

BY F. MEL1)E.

The author gives the following extract from a longer memoir which is shortly to appear.

By membranous bodies he understands such bodies as are capable of forming a membrane, which can be used for all purposes for which membranes can be applied. To these belong, for instance, the various kinds of paper, linen and cotton materials, caoutchouc, animal membranes, and so forth. The velocity of sound in such bodies differs greatly, but can be easily determined by fixing narrow strips at both ends, rubbing them in the middle, and determining the pitch of the fundamental note. If the number of vibrations is $n$, and the length of the strip $\mathbf{L}$, then $\mathrm{L}=\stackrel{\lambda}{\lambda}$ and $2 \mathrm{~L}=\lambda=$ the wave-leugth of the note in question; so that the velocity is $v=n \lambda$. In this way the following numbers were obtained for the velocity of sound.

\begin{tabular}{|c|c|}
\hline & \\
\hline d parchment-paper ... & \\
\hline silk paper ........ & 2046 \\
\hline$\ldots \ldots \ldots$ & \\
\hline & \\
\hline & \\
\hline & \\
\hline & \\
\hline & \\
\hline & \\
\hline cross-ribbed silk ribbon $\ldots$ & \\
\hline Black wax cloth $\quad \ldots, \ldots \ldots \ldots$ & \\
\hline
\end{tabular}

Beibläter der Physik, vol. xv. p. 756.

THE SOLITARY WAVE : CORRECTION OF A SIGN.

To the Editors of the Philosophical Magazine and Journal.

University College, Dundee, Genthemen, January 12, 1892.

In my " Note supplementary to a Paper on the Solitary Wave," which appeared in the December number of your Magazine, one of the expressions is written with a wrong sign, and might therefore prove somewhat misleading. The series given in the second line of page 555, the expansion of equation (5) of my paper "On the Solitary Wave" (Phil. Mag. July 1891), for the case of $x$ negative, should be affected with the negative sign. Were this not corrected it might appear to affect the argument, at least if one were to attend only to the series as written, neglecting its connexion with (5).

I am, Gentlemen,

Yours faithfully, John MeCowan. 